\title{
The effect of valproic acid on plasma level of carbamazepine and carbamazepine-10, 11-epoxide in long-term treatment with slow-release drug formulations in pediatric patients: the importance of TDM
}

\author{
Blanka Kořístková', 2, Milan Grundmann 1, 2, Hana Brozmanová1, 2, Ivana Kacírovái, 2 \\ 'Ústav klinické farmakologie, Lékařská fakulta, Ostravská Univerzita, Ostrava \\ ${ }^{2}$ Oddělení klinické farmakologie, Ústav laboratorní medicíny, Fakultní nemocnice Ostrava
}

The effect of valproic acid (VPA) on plasma level of carbamazepine (CBZ) and carbamazepine-10,11-epoxide (CBZ-E) in long-term treatment was evaluated.

Method: A total of 262 samples were obtained predose from 175 pediatric patients ( $<15$ years). Daily dose (PDD), dose related to bodyweight (DBW), plasma levels (PL) of CBZ, CBZ-E, CBZ level/dose ratio, CBZ-E level/dose ratio and CBZ-E/CBZ ratio, the distribution of PL according to the therapeutic range $4-9 \mathrm{mg} / \mathrm{L}$, and seizure frequency were compared. A detailed analysis was done in 11 individuals who served as their own control.

Results (given as mean \pm SD): Patients on a CBZ + VPA regimen were treated with higher daily doses: PDD $557 \pm 204$ vs. $400 \pm$ $187 \mathrm{mg}$, respectively, $\mathrm{p}<0.001$; DBW $20.2 \pm 10.5 \mathrm{vs} .13 .5 \pm 5.8 \mathrm{mg} / \mathrm{kg}$, respectively, $\mathrm{p}<0.001$. The mean CBZ PL and the distribution of PL according to the therapeutic range were not different: $5.1 \pm 1.4 \mathrm{vs.} 5.3 \pm 1.9 \mathrm{mg} / \mathrm{L}$, respectively. There was $86 \%$ of therapeutic PL CBZ + VPA and 77\% in monotherapy. No toxic level was found. CBZ-E PL remained unchanged in CBZ + VPA (1.2 \pm 0.8 vs. $1.1 \pm$ $0.9 \mathrm{mg} / \mathrm{L}$, respectively) as did the $\mathrm{CBZ}-\mathrm{E} / \mathrm{CBZ}$ ratio $(0.24 \pm 0.12$ vs. $0.22 \pm 0.19$, respectively).

The CBZ level/dose was decreased in CBZ + VPA: $10.3 \times 10^{-3} \pm 4.2 \times 10^{-3} \mathrm{vs} .14 .9 \times 10^{-3} \pm 6.4 \times 10^{-3} \mathrm{mg} \times \mathrm{L}^{-1} / \mathrm{mg}$, respectively, $\mathrm{p}<0.001$; so was the CBZ level/DBW: $0.31 \pm 0.17$ vs. $0.44 \pm 0.19 \mathrm{mg} \mathrm{L}^{-1} / \mathrm{mg} \times \mathrm{kg}^{-1}, \mathrm{p}<0.001$. These findings suggest an inductive effect of VPA on CBZ metabolism. Similar outcomes were found in 11 individuals who served as their own control: CBZ level/dose $10.9 \times 10^{-3} \pm$ $3.7 \times 10^{-3}$ vs. $15.0 \times 10^{-3} \pm 5.7 \times 10^{-3}$, respectively, $\mathrm{p}<0.01$; CBZ level/DBW $0.35 \pm 0.10$ vs. $0.40 \pm 0.14$, respectively, $\mathrm{p}<0.05$.

Dose-dependent adverse drug reactions (ataxia, headache) were reported in four individuals on CBZ monotherapy. No difference in the mean PL of CBZ or CBZ-E was found, while the CBZ-E/CBZ ratio and CBZ-E level/dose ratio were increased: $6.8 \times 10^{-3} \pm 1.6 \times 10^{-3}$ vs. $3.1 \times 10^{-3} \pm 3.6 \times 10^{-3}$, and $0.32 \pm 0.06$ vs. $0.21 \pm 0.20, p<0.05$ ). No difference in seizure frequency was found.

Conclusion: The CBZ-VPA interaction is considerable, but it is sufficiently eliminated due to TDM dose adjustment.

Key words: carbamazepine, carbamazepine-epoxide, valproic acid, drug-drug, interaction, slow-release drug formulations.

Vliv kyseliny valproové na hladinu karbamazepinu a karbamazepin-10,11-epoxidu při dlouhodobé léčbě přípravky s pomalým uvolňováním u dětí, význam TDM

Účel studie: Hodnocení vlivu kyseliny valproové (VPA) na hladinu karbamazepinu (CBZ) a karbamazepin-10,11-epoxidu (CBZ-E) při dlouhodobé léčbě prípravky s pomalým uvolňováním.

Metoda: $\cup 262$ vzorků odebraných před podáním od 175 dětských pacientů (< 15 let) byla hodnocena celková denní dávka (PDD), dávka na kg (DBW), koncentrace CBZ, CBZ-E, poměry CBZ koncentrace/PDD, CBZ-E koncentrace/PDD, CBZ-E/CBZ a rozložení koncentrací CBZ ve vztahu k terapeutickému rozmezí 4-9 mg. Podrobná analýza byla provedena u 11 pacientů, kteří byli vlastní kontrolou. 


\section{PŮVODNÍ PRÁCE}

THE EFFECT OF VALPROIC ACID ON PLASMA LEVEL OF CARBAMAZEPINE AND CARBAMAZEPINE-10, 11-EPOXIDE IN LONG-TERM TREATMENT WITH SLOW-RELEASE DRUG FORMULATIONS IN PEDIATRIC PATIENTS; THE IMPORTANCE OF TDM

Výsledky (uvedeny jako průměr \pm směrodatná odchylka): Ačkoliv pacienti léčení CBZ + VPA užívali vyšší dávky než pacienti na monoterapii: PDD $557 \pm 204$ vs. $400 \pm 187$ mg, p <0.001; DBW $20.2 \pm 10.5$ vs. $13.5 \pm 5.8 \mathrm{mg} / \mathrm{kg}, \mathrm{p}<0.001$, nebyl zaznamenán rozdíl v průměrné koncentraci CBZ (5.1 \pm 1.4 vs. $5.3 \pm 1.9 \mathrm{mg} / \mathrm{l})$, CBZ-E $(1.2 \pm 0.8$ vs. $1.1 \pm 0.9 \mathrm{mg} / \mathrm{l})$, poměru CBZ-E/CBZ $(0.24 \pm 0.12 \mathrm{vs} .0 .22 \pm$ 0.19) ani v rozložení koncentrací podle terapeutického rozmezí. V terapeutickém optimu bylo $86 \%$ vs. $77 \%$ koncentrací. Koncentrace nad horní hranicí terapeutického rozmezí se nevyskytovaly. U CBZ + VPA byly nižší pomèry koncentrace CBZ/PDD: $10.3 \times 10^{-3} \pm 4.2 \times$ $10^{-3}$, vs. $14.9 \times 10^{-3} \pm 6.4 \times 10^{-3} \mathrm{mg} \times \mathrm{L}^{-1} / \mathrm{mg}, \mathrm{p}<0.001 ; \mathrm{CBZ} / \mathrm{DBW}: 0.31 \pm 0.17$, vs. $0.44 \pm 0.19 \mathrm{mg}^{-1} / \mathrm{mg}^{-1} \times \mathrm{kg}^{-1}, \mathrm{p}<0.001$. Obdobně u 11 pacientů, kteří byli vlastní kontrolou: poměr koncentrace CBZ/PDD $10.9 \times 10^{-3} \pm 3.7 \times 10^{-3} \mathrm{vs.} 15.0 \times 10^{-3} \pm 5.7 \times 10^{-3}, \mathrm{p}<0.01 ; \mathrm{CBZ} / \mathrm{DBW}$ $0.35 \pm 0.10$ vs. $0.40 \pm 0.14, p<0.05$. Zdá se, že VPA má indukční efekt na metabolismus CBZ. Na dávce závislé nežádoucí účinky (ataxie, bolest hlavy) byly popsány u 4 pacientů na monoterapii. Koncentrace CBZ a CBZ-E se nelišila od pacientů bez NÚL, byl však vyšší pomèr CBZ-E/CBZ $6.8 \times 10^{-3} \pm 1.6 \times 10^{-3}$ vs. $3.1 \times 10^{-3} \pm 3.6 \times 10^{-3}$, a CBZ-E/PDD $0.32 \pm 0.06$ vs. $0.21 \pm 0.20, p<0.05$.

Závěr: Významná interakce mezi CBZ a VPA byla úspěšně eliminována úpravou dávkování pomocí TDM.

Klíčová slova: karbamazepin, karbamazepin-epoxid, kyselina valproová, interakce, léčivé přípravky s pomalým uvolňováním.

\section{Introduction}

Carbamazepine (CBZ) and valproic acid (VPA) are the drugs of choice in the treatment of epilepsy. Their concomitant administration is quite common (1-3).

CBZ is extensively metabolized in the liver, primarily by CYP $3 A 4$, to active carbamazepine-10,11-epoxide (CBZ-E) $(4,5)$ whereas CYP2C8 is a minor pathway (5). CBZ-E is further metabolized by epoxide-hydrolase to inactive 10,11-dihydro-carbamazepine (carbamazepine-diol), which is consequently conjugated with glucuronic acid by uridine diphosphate glucuronosyltransferase (UGT) $(4,5)$. In long-term treated patients, 30-50\% of carbamazepine-diol is excreted directly into urine (5).

Even though CBZ and VPA have been in use since the $1960 \mathrm{~s}(1,6)$, there is no consensus regarding the clinical relevance of VPA effects on carbamazepine metabolism (5), with both increases and decreases in the CBZ level having been observed (7). Carbamazepine-10,11epoxide level was reported to be increased with concurrent use of valproate $(3,5,7,8)$.

CBZ is known as an inducer of cytochrome CYP3A4, CYP2C and epoxide hydrolase (9), and its own metabolism is susceptible to autoinduction after repeated administration $(2,7,8)$. The autoinduction is reported to be finished after one month of drug administration (5). CBZ-E also induces its own metabolism in a way similar to CBZ (10). VPA is an inhibitor of epoxide hydrolase $(1,9,11)$ and nonspecifically inhibits all steps of the epoxide-diol pathway of CBZ metabolism in children (12). Significant positive correlations have been found between the VPA level and CBZ-E/CBZ ratio, as well as the CBZ level/dose ratio in children (13).

The aim was to study the effect of valproic acid on carbamazepine concentration during long-term treatment in pediatric epileptic patients.

\section{Material and method}

Request and reply forms for therapeutic drug monitoring of antiepileptic drugs examined during the period 1997-2002 were used as a data source. A total of 262 of samples taken predose obtained from 175 pediatric patients (i. e., younger than 15 years) were included. The characteristic of the cohort is given in Table 1. Eleven patients treated with both CBZ monotherapy and CBZ + VPA were included in both groups. These 11 patients who served as their own control were also analyzed in detail.

Inclusion criteria: Long-term treatment with slow-release forms of carbamazepine (Timonil, Tegretol, Neurotop) or valproic acid (Depakine, Orfiril, Convulex).

Exclusion criteria: Suspected non-compliance (i.e., a plasma level of CBZ $<1 \mathrm{mg} / \mathrm{L}$ and of VPA $<10 \mathrm{mg} / \mathrm{L}$ ), once daily treatment regimen. Patients treated with other drugs were excluded with an exception of magnesium, nootropics (piracetam, pyritinol), and vitamins.

Dosage (absolute daily dose, dose related to body weight), plasma levels of CBZ, CBZ-E, CBZ level/dose ratio, CBZ-E level/dose ratio, CBZ-E/CBZ, and CBZ + CBZ-E were evaluated. The distribution of plasma levels according to the therapeutic range $4-9 \mathrm{mg} / \mathrm{L}$ and the incidence of adverse drug reactions, such as nystagmus, dizziness, bradypsychia, ataxia, headache, and nausea, were analyzed.

The frequency of seizures was divided into four categories: occurrence of seizures daily, monthly, several seizures per year, and being seizure-free more than one year. Statistics were calculated from answered questions only.

All samples were included in patients examined repeatedly, while means per patient were used in a detailed analysis of 11 individuals who served as their own control.

\section{Analysis of plasma levels}

CBZ and CBZ-E plasma levels were determined using high-performance liquid chromatography (HPLC) (14). Plasma levels of VPA were assayed with gas-liquid chromatography (GLC) (15). Both methods were fully validated and participated in external quality control schemes - RfB Referenzinstitut für Bioanalytik.

\section{Statistics}

Differences between means were compared using the Student's t-test (two-tailed) The Chi-square test was used to analyze the distribution of plasma levels according to the therapeutic range (16) and for seizure frequency (17).

\section{Results}

The patients on the CBZ + VPA regimen were treated with significantly higher daily doses (absolute as well as related to the body weight) while mean plasma levels of $C B Z$ and CBZ-E were not different (Table 2). The dose of valproic acid was (mean \pm SD) $691 \pm 218 \mathrm{mg}$, DBW was $25.15 \pm 11.83 \mathrm{mg} \mathrm{kg}^{-1}$, and VPA level was $52.57 \pm 17.25 \mathrm{mg} \cdot \mathrm{L}^{-1}$. 
The concentration ratio of CBZ-E/CBZ was unchanged. The CBZ level/dose ratio as well as CBZ-E level/dose ratio were lower in patients on the CBZ+VPA regimen (Table 3). This suggests an increased clearance of CBZ and CBZ-E.

The distribution according to the therapeutic range was similar in both regimens. No level was found above the older upper margin, i.e., $12 \mathrm{mg} / \mathrm{L}$. When the CBZ + CBZ-E level was counted together, 6 (3\%) levels above $12 \mathrm{mg} / \mathrm{L}$ in CBZ monotherapy were found (Table 4). Generally, CBZ levels tended to target concentrations at the lower end of the therapeutic range (Fig. 1).

Adverse drug reactions were found in four individuals on CBZ monotherapy (Table 5). No difference in mean CBZ or CBZ-E levels was found when compared with patients without toxic events, while the CBZ-E/CBZ ratio and CBZ-E level/dose ratio were increased $\left(6.82 \times 10^{-3} \pm 1.61 \times 10^{-3}\right.$ vs. $3.14 \times 10^{-3} \pm 3.62 \times$ $10^{-3}$, and $0.321 \pm 0.061$ vs. $0.214 \pm 0.197, p<0.05$ ).

Information on seizure frequency was given in 148 request forms (56\%). The difference between $C B Z$ and $C B Z+V P A$ was not significant (Table 6).

\section{Analysis of 11 patients who served as their own control}

The cohort characteristic and dosage of CBZ in 11 patients that served as their own control is given in Table 7. The VPA dosage and plasma levels are given in Table 8. Six patients only reached the therapeutic range 50-100 mg/L.

Patients treated with $C B Z+V P A$ received significantly higher daily doses, while CBZ levels, CBZ-E levels, and CBZ-E/CBZ ratios were not different. All levels reached the therapeutic range $4-9 \mathrm{mg} / \mathrm{L}$ in monotherapy, while two dropped below when VPA was added (Table 9). A significantly lower mean CBZ level/ dose ratio as well as mean $C B Z$ level/DBW ratio were found in the CBZ+VPA group (Table 1). No adverse drug reactions were reported in this cohort.

\section{Discussion}

The CBZ plasma level and the distribution of plasma levels according to the therapeutic range were similar in both regimens. The lack of an effect of VPA on plasma level of CBZ is

Tab. 1. The characteristic of the cohort

\begin{tabular}{l|c|c|}
\hline & CBZ alone & CBZ+VPA \\
\hline number of patients & 143 & 32 \\
\hline number of samples & 209 & 53 \\
\hline age $[\mathrm{yr}]^{+}$ & $8.8 \pm 3.2$ & $10.0 \pm 2.6^{* *}$ \\
\hline weight $[\mathrm{kg}]^{+}$ & $32.2 \pm 13.6$ & $30.7 \pm 11.1$ \\
\hline
\end{tabular}

Tab. 2. The dosage and plasma levels of carbamazepine and carbamazepine-10,11-epoxide

\begin{tabular}{|l|c|c|c|}
\hline & CBZ & CBZ+VPA & difference \\
\hline dose $[\mathrm{mg}]$ & $400 \pm 187$ & $557 \pm 204$ & $39 \%^{* * *}$ \\
\hline dose related to body weight $[\mathrm{mg} / \mathrm{kg}]$ & $13.5 \pm 5.8$ & $20.2 \pm 10.5$ & $50 \%^{* * *}$ \\
\hline CBZ level $[\mathrm{mg} / \mathrm{L}]$ & $5.3 \pm 1.9$ & $5.1 \pm 1.4$ & $-3 \%$ \\
\hline CBZ-E level $[\mathrm{mg} / \mathrm{L}]$ & $1.1 \pm 0.9$ & $1.2 \pm 0.8$ & $10 \%$ \\
\hline CBZ-E/CBZ & $0.22 \pm 0.19$ & $0.24 \pm 0.12$ & $12 \%$ \\
\hline CBZ+CBZ-E [mg/L] & $6.3 \pm 2.3$ & $6.3 \pm 1.6$ & $-1 \%$ \\
\hline
\end{tabular}

The values are given as mean $\pm S D,{ }^{* * *} p<0.0001 ;{ }^{* *} p<0.01$

Tab. 3. Level/dose ratios of carbamazepine and carbamazepine-10,11-epoxide

\begin{tabular}{|c|c|c|c|}
\hline & CBZ & CBZ+VPA & difference \\
\hline CBZ level/dose $\left[\mathrm{mg} \times \mathrm{L}^{-1} / \mathrm{mg}\right]$ & $14.9 \times 10^{-3} \pm 6.4 \times 10^{-3}$ & $10.3 \times 10^{-3} \pm 4.2 \times 10^{-3}$ & $-31 \%^{* * *}$ \\
\hline CBZ level/DBW $\left[\mathrm{mg} \times \mathrm{L}^{-1} / \mathrm{mg} \times \mathrm{kg}^{-1}\right]$ & $0.44 \pm 0.19$ & $0.31 \pm 0.17$ & $-29 \%^{* * *}$ \\
\hline CBZ-E level/dose $\left[\mathrm{mg} \times \mathrm{L}^{-1} / \mathrm{mg}\right]$ & $3.2 \times 10^{-3} \pm 3.6 \times 10^{-3}$ & $2.4 \times 10-3 \pm 1.5 \times 10^{-3}$ & $-24 \%^{*}$ \\
\hline CBZ-E level/DBW $\left[\mathrm{mg} \times \mathrm{L}^{-1} / \mathrm{mg} \times \mathrm{kg}^{-1}\right]$ & $90.1 \times 10^{-3} \pm 90.3 \times 10^{-3}$ & $72.8 \times 10-3 \pm 52.0 \times 10^{-3}$ & $-19 \%$ \\
\hline
\end{tabular}

Tab. 4. The distribution of CBZ concentrations related to therapeutic range (TR) 4-9mg/L

\begin{tabular}{|l|c|c|c|c|c|}
\hline & \multicolumn{2}{|c|}{ regimen } & \multicolumn{3}{c|}{ plasma level } \\
\hline \multirow{3}{*}{ CBZ level } & & $0-3.9$ & $4-9$ & $>9$ & $>12 \mathrm{mg} / \mathrm{L}$ \\
\cline { 2 - 6 } & $\mathrm{CBZ}$ & $49(23 \%)$ & $153(73 \%)$ & $7(3 \%)$ & 0 \\
\hline \multirow{2}{*}{ CBZ+CBZ-E level } & $\mathrm{CBZ}+\mathrm{VPA}$ & $10(19 \%)$ & $43(81 \%)$ & & \\
\cline { 2 - 6 } & $\mathrm{CBZ}$ & $24(11 \%)$ & $157(75 \%)$ & $28(13 \%)$ & $6(3 \%)$ \\
\cline { 2 - 6 } & $\mathrm{CBZ}+\mathrm{VPA}$ & $4(7.5 \%)$ & $49(92.5 \%)$ & & \\
\hline
\end{tabular}

Tab. 5. The type of adverse drug reaction in relation with CBZ and CBZ-E levels and their ratios in order to CBZ level

\begin{tabular}{|l|c|c|c|c|c|}
\hline Patient No. & CBZ level & CBZ-E level & CBZ-E/CBZ & CBZ + CBZ-E & adverse drug reaction \\
\hline 1 & 2.8 & 1.0 & 0.357 & 3.8 & headache \\
\hline 2 & 5.1 & 1.3 & 0.255 & 6.4 & ataxia \\
\hline 3 & 8.1 & 2.3 & 0.284 & 10.4 & ataxia \\
\hline 4 & 10.1 & 3.9 & 0.386 & 14 & ataxia \\
\hline
\end{tabular}

Tab. 6. Seizure frequency

\begin{tabular}{|l|c|c|c|c|c|}
\hline & NR/total & daily & monthly & yearly & none \\
\hline CBZ & $90 / 209$ & $10(8 \%)$ & $37(31 \%)$ & $51(43 \%)$ & $10(18 \%)$ \\
\hline CBZ + VPA & $24 / 53$ & $5(21 \%)$ & $9(31 \%)$ & $12(41 \%)$ & $5(7 \%)$ \\
\hline
\end{tabular}

NR not reported. Percentages are calculated from answered questionnaires only.

apparent at first sight. However, these findings are a result of significantly higher daily doses as well as DBW in the CBZ+VPA group. The CBZ level/dose ratio was significantly decreased in CBZ + VPA in the whole cohort as well as in 11 patients who served as their own control. This reflects increased CBZ clearance. Similar findings were described by Levy et al (18) in a cohort of seven patients (both children and adults), by Liu et al (13) in children, and by Rambeck et al (19) in adults. Shoeman et al
(20) also found a decreased CBZ level which, however, was not significant. By contrast, Svinarov et al (12) found an increased CBZ level/dose ratio in CBZ + VPA in children, but a decreased ratio in adults two months after treatment initiation. Potter et al (3) reported similar mean $C B Z$ concentrations in both $C B Z$ and $C B Z+V P A$ groups, but information on the dosage is lacking. Bernus et al (21) reviewed five studies with no appreciable change in the CBZ plasma level. 


\section{PŮVODNÍ PRÁCE}

THE EFFECT OF VALPROIC ACID ON PLASMA LEVEL OF CARBAMAZEPINE AND CARBAMAZEPINE-10, 11-EPOXIDE IN LONG-TERM TREATMENT WITH SLOW-RELEASE DRUG FORMULATIONS IN PEDIATRIC PATIENTS; THE IMPORTANCE OF TDM

Tab. 7. The cohort characteristics of 11 patients treated with both CBZ and CBZ+VPA

\begin{tabular}{|c|c|c|c|c|c|c|c|}
\hline \multirow[t]{2}{*}{ No. } & \multirow[t]{2}{*}{ gender } & \multirow[t]{2}{*}{ age $[y r]$} & \multirow[t]{2}{*}{ body weight [kg] } & \multicolumn{2}{|c|}{ CBZ dose [mg] } & \multicolumn{2}{|c|}{ CBZ DBW [mg/kg] } \\
\hline & & & & CBZ & $\mathrm{CBZ}+\mathrm{VPA}$ & CBZ & $C B Z+V P A$ \\
\hline 1 & $\mathrm{~F}$ & 9 & 26 & 200 & 200 & 7.69 & 7.69 \\
\hline 2 & M & 5 & 23 & 288 & 500 & 14.32 & 17.45 \\
\hline 3 & $\mathrm{~F}$ & 10 & 33 & 300 & 375 & 9.68 & 10.97 \\
\hline 4 & $\mathrm{~F}$ & 7 & 27 & 325 & 375 & 13.18 & 11.36 \\
\hline 5 & $\mathrm{~F}$ & 8 & 27 & 375 & 675 & 18.75 & 22.27 \\
\hline 6 & M & 11 & 31 & 375 & 600 & 13.06 & 17.71 \\
\hline 7 & $\mathrm{~F}$ & 7 & 20 & 412 & 375 & 20.09 & 19.74 \\
\hline 8 & M & 10 & 43 & 488 & 638 & 11.72 & 14.56 \\
\hline 9 & M & 10 & 30 & 525 & 525 & 18.10 & 17.50 \\
\hline 10 & M & 12 & 50 & 525 & 750 & 10.71 & 15.00 \\
\hline 11 & M & 10 & 24 & 600 & 700 & 31.58 & 25.83 \\
\hline mean \pm SD & & $9 \pm 2$ & $30 \pm 8$ & $401 \pm 122$ & $519 \pm 172^{* *}$ & $15.4 \pm 6.6$ & $16.4 \pm 5.2^{* *}$ \\
\hline
\end{tabular}

Tab. 8. The dosage and plasma levels of valproic acid

\begin{tabular}{|l|c|c|c|}
\hline No. & dose $[\mathbf{m g}]$ & DBW $[\mathbf{m g} / \mathbf{k g}]$ & plasma level $[\mathrm{mg} / \mathbf{L}]$ \\
\hline 1 & 75 & 2.9 & 33.0 \\
\hline 2 & 750 & 26.7 & 57.5 \\
\hline 3 & 525 & 15.4 & 57.2 \\
\hline 4 & 500 & 15.2 & 42.7 \\
\hline 5 & 750 & 25.0 & 68.8 \\
\hline 6 & 750 & 21.9 & 46.6 \\
\hline 7 & 500 & 26.3 & 40.0 \\
\hline 8 & 438 & 9.9 & 39.8 \\
\hline 9 & 250 & 8.3 & 39.1 \\
\hline 10 & 500 & 10.0 & 36.0 \\
\hline 11 & 600 & 22.5 & 35.8 \\
\hline mean \pm SD & $513 \pm 211$ & $16.7 \pm 8.2$ & $45.1 \pm 11.3$ \\
\hline
\end{tabular}

DBW - dose related to body weight

Tab. 9. Plasma levels of carbamazepine, carbamazepine-10,11-epoxide and CBZ-E/CBZ ratio in 11 patients treated with both CBZ and CBZ + VPA

\begin{tabular}{|l|c|c|c|c|c|c|}
\hline No & \multicolumn{2}{|c|}{ CBZ level $[\mathrm{mg} / \mathrm{L}]$} & \multicolumn{2}{c|}{ CBZ-E level $[\mathrm{mg} / \mathrm{L}]$} & \multicolumn{2}{c|}{ CBZ-E/CBZ } \\
\hline & $\mathrm{CBZ}$ & $\mathrm{CBZ}+\mathrm{VPA}$ & $\mathbf{C B Z}$ & $\mathrm{CBZ}+\mathrm{VPA}$ & $\mathbf{C B Z}$ & $\mathrm{CBZ}+$ VPA \\
\hline 1 & 5.2 & 3.8 & 0.6 & 0.4 & 0.12 & 0.11 \\
\hline 2 & 6.0 & 4.6 & 1.18 & 0.8 & 0.19 & 0.19 \\
\hline 3 & 4.7 & 5.1 & 0.9 & 0.7 & 0.19 & 0.14 \\
\hline 4 & 4.6 & 2.4 & 0.7 & 1.1 & 0.15 & 0.46 \\
\hline 5 & 6.5 & 6.5 & 1.6 & 1.8 & 0.25 & 0.28 \\
\hline 6 & 4.8 & 5.0 & 0.25 & 1.1 & 0.05 & 0.21 \\
\hline 7 & 4.4 & 5.0 & 1.4 & 2.3 & 0.32 & 0.46 \\
\hline 8 & 5.7 & 6.6 & 1.15 & 1.7 & 0.20 & 0.28 \\
\hline 9 & 8.6 & 6.7 & 0.9 & 1.1 & 0.10 & 0.16 \\
\hline 10 & 4.0 & 4.6 & 0.8 & 0.8 & 0.20 & 0.17 \\
\hline 11 & 5.3 & 5.6 & 1.7 & 0.8 & 0.32 & 0.14 \\
\hline mean \pm SD & $5.4 \pm 1.3$ & $5.1 \pm 1.2$ & $1.0 \pm 0.4$ & $1.1 \pm 0.6$ & $0.19 \pm 0.08$ & $0.24 \pm 0.12$ \\
\hline
\end{tabular}

Liu et al (13) also mentioned a significant decrease in the CBZ level/dose ratio in the presence of VPA.

An increase in the CBZ-E level and CBZ-E/CBZ ratio in CBZ + VPA reported by Liu et al (13) and Potter et al (3) was not observed in our study.

Liu et al further described a CBZ-E/dose increase while we found a significant decrea- zyme site (2) and occurs immediately after treatment initiation, while enzymatic induction requires the synthesis of a new protein, which may take several days or weeks (13). This mechanism is supported by the finding of Liu et al (13) who found a significant decrease in the CBZ level/dose ratio in CBZ+VPA and together positive correlation between this ratio and VPA level. They also described a significantly increased CBZ free fraction as a result of relatively decreased total CBZ level with almost unchanged free CBZ concentration. An increase in the free fraction described by Levy et al (18) was also suggested as a reason for CBZ level decrease in the presence of VPA.

A third mechanism involved may be incomplete absorption described in high doses of CBZ (10) which might be deepened with lower bioavailability of retard tablets, that we found in our previous study (22). Lower bioavailability might also explain the lower CBZ level/dose ratio when compared with the observation by Liu et al (13).

Similarly to us, Potter et al (3) pointed out that clinicians tended to target concentrations at the lower end of the therapeutic range.

When therapeutic drug monitoring is performed, the dose of CBZ is stepwise increased according to the TDM outcomes, similar CBZ levels are reached, and the clinical effect of the interaction is thus eliminated.

The TDM outcomes must be interpreted in relation with dosage, otherwise incorrect conclusions might be drawn.

Limitations: Non-adherence of physicians to some questions on the request forms (mentioned also by Morris et al. (23), especially those regarding seizure frequency or occurrence of ADRs, represents a difficulty for data evaluation. In the case of ADRs, we cannot distinguish whether they were not reported because they did not occur or because of simple non-adherence. Considering this fact, we decided to show the percentage of the incidence of ADRs from the whole group.

Potential under-reporting of ADRs or inaccuracies regarding seizure frequency on the request form are inherent to the retrospective and pragmatic nature of this study. 
PŮVODNÍ PRÁCE I

Tab. 10. Level/dose ratios of carbamazepine and carbamazepine-10,11-epoxide in 11 patients treated with both CBZ and CBZ + VPA

\begin{tabular}{|c|c|c|c|c|c|c|c|c|}
\hline \multirow[t]{2}{*}{ No } & \multicolumn{2}{|c|}{$\begin{array}{c}\text { CBZ level/dose } \\
{\left[\mathrm{mg} \times \mathrm{L}^{-1} / \mathrm{mg}\right]}\end{array}$} & \multicolumn{2}{|c|}{$\begin{array}{c}\text { CBZ-E level/dose } \\
{\left[\mathrm{mg} \times \mathrm{L}^{-1} / \mathrm{mg}\right]}\end{array}$} & \multicolumn{2}{|c|}{$\begin{array}{c}\text { CBZ level/DBW } \\
{\left[\mathrm{mg} \times \mathrm{L}^{-1} / \mathrm{mg} \times \mathrm{kg}^{-1}\right]}\end{array}$} & \multicolumn{2}{|c|}{$\begin{array}{c}\text { CBZ-E level/DBW } \\
{\left[\mathrm{mg} \times \mathrm{L}^{-1} / \mathrm{mg} \times \mathrm{kg}^{-1}\right]}\end{array}$} \\
\hline & CBZ & $C B Z+V P A$ & CBZ & $C B Z+V P A$ & CBZ & $C B Z+V P A$ & CBZ & $C B Z+V P A$ \\
\hline 1 & $26.0 \times 10^{-3}$ & $19.0 \times 10^{-3}$ & $30 \times 10^{-3}$ & $2.0 \times 10^{-3}$ & 0.676 & 0.494 & $78.0 \times 10^{-3}$ & $52.0 \times 10^{-3}$ \\
\hline 2 & $23.4 \times 10^{-3}$ & $10.7 \times 10^{-3}$ & $48 \times 10^{-3}$ & $1.8 \times 10^{-3}$ & 0.430 & 0.298 & $81.8 \times 10^{-3}$ & $48.8 \times 10^{-3}$ \\
\hline 3 & $15.7 \times 10^{-3}$ & $13.3 \times 10^{-3}$ & $30 \times 10^{-3}$ & $1.8 \times 10^{-3}$ & 0.486 & 0.454 & $93.0 \times 10^{-3}$ & $61.8 \times 10^{-3}$ \\
\hline 4 & $14.5 \times 10^{-3}$ & $6.4 \times 10^{-3}$ & $21 \times 10^{-3}$ & $2.9 \times 10^{-3}$ & 0.352 & 0.211 & $51.9 \times 10^{-3}$ & $96.8 \times 10^{-3}$ \\
\hline 5 & $17.3 \times 10^{-3}$ & $10.8 \times 10^{-3}$ & $43 \times 10^{-3}$ & $2.9 \times 10^{-3}$ & 0.347 & 0.321 & $85.3 \times 10^{-3}$ & $87.5 \times 10^{-3}$ \\
\hline 6 & $12.9 \times 10^{-3}$ & $8.3 \times 10^{-3}$ & $07 \times 10^{-3}$ & $1.8 \times 10^{-3}$ & 0.367 & 0.287 & $20.2 \times 10^{-3}$ & $60.3 \times 10^{-3}$ \\
\hline 7 & $10.4 \times 10^{-3}$ & $13.3 \times 10^{-3}$ & $34 \times 10^{-3}$ & $6.1 \times 10^{-3}$ & 0.215 & 0.253 & $69.3 \times 10^{-3}$ & $116.5 \times 10^{-3}$ \\
\hline 8 & $11.6 \times 10^{-3}$ & $10.3 \times 10^{-3}$ & $23 \times 10^{-3}$ & $2.6 \times 10^{-3}$ & 0.484 & 0.458 & $96.2 \times 10^{-3}$ & $114.7 \times 10^{-3}$ \\
\hline 9 & $16.4 \times 10^{-3}$ & $12.8 \times 10^{-3}$ & $17 \times 10^{-3}$ & $2.1 \times 10^{-3}$ & 0.475 & 0.383 & $49.7 \times 10^{-3}$ & $62.9 \times 10^{-3}$ \\
\hline 10 & $7.6 \times 10^{-3}$ & $6.1 \times 10^{-3}$ & $15 \times 10^{-3}$ & $1.1 \times 10^{-3}$ & 0.373 & 0.307 & $74.7 \times 10^{-3}$ & $53.3 \times 10^{-3}$ \\
\hline 11 & $8.8 \times 10^{-3}$ & $8.3 \times 10^{-3}$ & $28 \times 10^{-3}$ & $1.1 \times 10^{-3}$ & 0.168 & 0.217 & $53.8 \times 10^{-3}$ & $29.1 \times 10^{-3}$ \\
\hline mean \pm SD & $\begin{aligned} 15.0 & \times 10^{-3} \pm 5.7 \\
& \times 10^{-3}\end{aligned}$ & $\begin{array}{l}10.9 \times 10^{-3} \pm \\
3.7 \times 10^{-3 * *}\end{array}$ & $\begin{array}{c}27 \times 10^{-3} \pm \\
12 \times 10^{-3}\end{array}$ & $\begin{array}{c}2.4 \times 10^{-3} \pm \\
1.4 \times 10^{-3}\end{array}$ & $0.397 \pm 0.139$ & $0.345 \pm 0.099^{*}$ & $\begin{array}{c}68.5 \times 10^{-3} \pm 22.7 \\
\times 10^{-3}\end{array}$ & $\begin{array}{c}71.3 \times 10^{-3} \pm 28.5 \\
\times 10^{-3}\end{array}$ \\
\hline
\end{tabular}

DBW - dose related to body weight, ${ }^{* *} p<0.01,{ }^{*} p<0.05$

\section{Conclusion}

The CBZ-VPA interaction is complicated, both increase and decrease in the CBZ level might occur. When therapeutic drug monitoring is performed, the dose of $\mathrm{CBZ}$ is balanced according to the TDM outcomes, similar CBZ levels are reached, and the clinical effect of the interaction is eliminated. It is important to interpret TDM outcomes in relation with dosage and concomitant therapy. Due to a CBZ level balance, the incidence of adverse drug reactions remained unchanged in $\mathrm{CBZ}+\mathrm{VPA}$.

\section{LITERATURA}

1. Perucca E. Pharmacological and therapeutic properties of valproate: a summary after 35 years of clinical experience. CNS Drugs 2002; 16: 695-714.

2. Tanaka. Clinically significant pharmacokinetic drug interactions between antiepileptic drugs. J Clin Pharm Ther 1999; 24: 87-92.

3. Potter JM, Donnelly A. Carbamazepine-10,11-epoxide in therapeutic drug monitoring. Ther Drug Monit 1998; 20: 652-657.

4. Patsalos PN, Spencer EP, Berry DJ. Therapeutic drug monitoring of antiepileptic drugs in epilepsy: a 2018 update. Ther Drug Monit. 2018; 40: 526-548.

5. Levy RH, Wurgen CJ. Carbamazepine. Interactions with other drugs. In: Levy RH, Mattson RH, Meldrum BS, eds. Antiepileptic Drugs. New York: Raven Press; 1995: 543-554.

6. Kerr BM, Levy RH. Carbamazepine. Carbamazepine epoxide. In: Levy RH, Mattson RH, Meldrum BS, eds. Antiepileptic Drugs. New York: Raven Press; 1995: 529-541.

7. Patsalos PN, Fröscher W, Pisani F et al. The importance of drug interactions in epilepsy therapy. Epilepsia 2002; 43: 365-385.

8. Spina E, Pisani F, Perucca E. Clinically significant pharmacokinetic drug interactions with carbamazepine, an update. Clin Pharmacokinet 1996; 31: 198-213.

9. Anderson GD. A mechanistic approach to antiepileptic drug

Fig. 1. Histogram of CBZ plasma levels. The therapeutic range is given by box

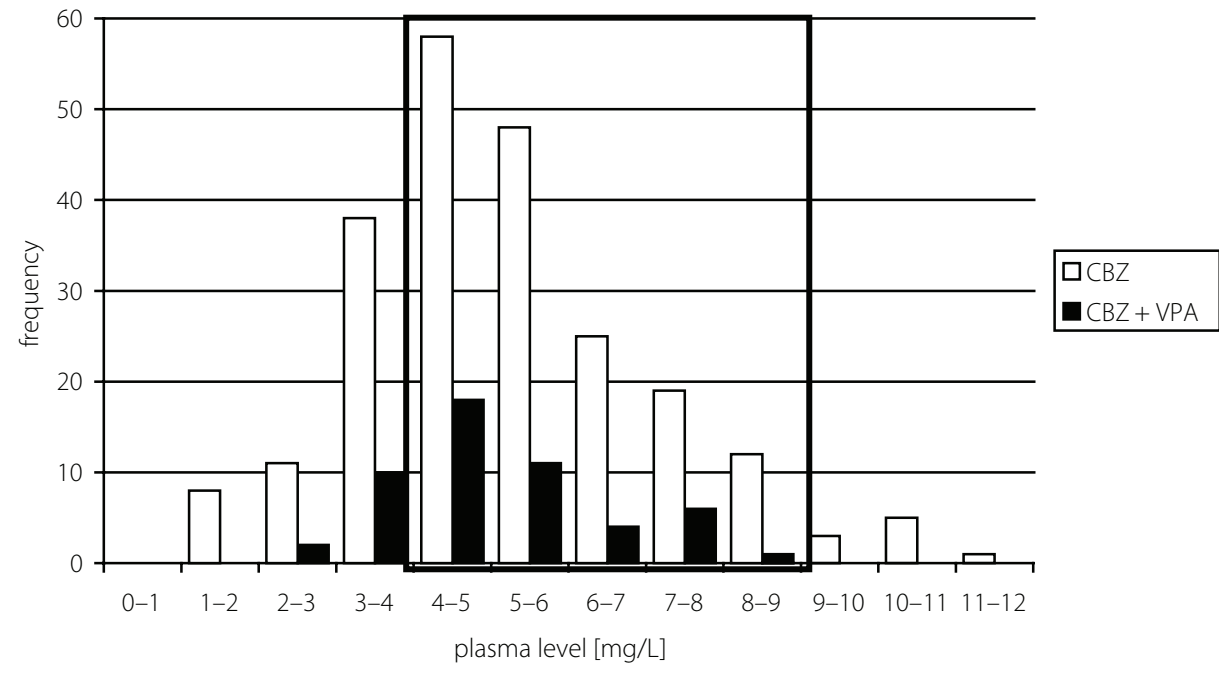

interactions. Ann Pharmacother 1998; 32: 554-563.

10. Arroyo S, Sander JWAS. Carbamazepine in comparative trials: pharmacokinetic characteristics too often forgotten. Neurology 1999; 53: 1170-1174.

11. Battino D, Estienne M, Avanzini G. Clinical pharmacokinetics of antiepileptic drugs in pediatric patients. Part I. Phenobarbital, primidone, valproic acid, ethosuximide and mesuximide. Clin Pharmacokinet 1995; 29: 257-286.

12. Svinarov DA, Pippenger CE. Valproic acid-carbamazepine interaction: Is valproic acid a selective inhibitor of epoxide hydrolase? Ther Drug Monit 1995; 17: 217-220.

13. Liu H, Delgado MR, Browne R. Interactions of valproic acid with carbamazepine and its metabolites' concentrations, concentration ratios, and level/dose ratios in epileptic children. Clin Neuropharmacol 1995; 18: 1-12.

14. Budakova L, Brozmanova H, Grundmann M et al. Simultaneous determination of antiepileptic drugs and their two active metabolites by HPLC. J Sep Sci. 2008; 31: 1-8.

15. Brozmanova H, Grundmann M. First experiences with therapeutic monitoring of antiepileptics [abstract]. Cesk Fysiol. 1985; 34: 416 [in Czech].

16. Epi Info [computer program]. Version 6.04b. Atlanta: Centers for Disease Control and Prevention; 1997.
17. Prism [computer program]. Version 5.0, San Diego: GraphPad Software, Inc.; 2007.

18. Levy RH, Moreland TA, Morseli et al. Carbamazepine/ valproic acid interaction in man and rhesus monkey. Epilepsia 1984; 25: 338-345.

19. Rambeck B, May T, Juergens U. Serum concentrations of carbamazepine and its epoxide and diol metabolites in epileptic patients: the influence of dose and comedication. Ther Drug Monit 1987; 9: 298-303.

20. Schoeman JF, Elyas AA, Brett EM et al. Altered ratio of carbamazepine-10,11-epoxide/carbamazepine in plasma of children: evidence of anticonvulsant drug interaction. Dev Med Child Neurol 1984; 26: 749-755.

21. Bernus I, Dickinson RG, Hooper WD et al. The mechanism of the carbamazepine-valproate interaction in humans. $\mathrm{Br} J$ Clin Pharmacol 1997; 44: 21-27.

22. Koristkova B, Grundmann M. Effect of a drug form change on the utilization of carbamazepine in hospital departments [In Czech]. Klin Farmacol Farmac 2000; 14: 19-22.

23. Morris RG, Black AB, Harris AL et al. Lamotrigine and therapeutic drug monitoring: retrospective survey following the introduction of a routine service. $\mathrm{Br} J$ Clin Pharmacol. 1998: 46: 547-551. 